\title{
Radiological appearance of primary extracranial meningioma of the pelvis in a middle-aged woman
}

\author{
Keerti Kyalakond, ${ }^{1}$ Shimona Saini, ${ }^{2}$ Kadavigere Rajagopal, ${ }^{3}$ \\ Lakshmikanth Halegubbi Karegowda ${ }^{3}$
}

\begin{abstract}
'Department of Obstetrics and Gynaecology, Manipal Academy of Higher Education, Kasturba Medical College, Manipal, Karnataka, India

${ }^{2}$ Department of Radiodiagnosis, Dr Ram Manohar Lohia Hospital and Post Graduate Institute of Medical Education and Research, New Delhi, India ${ }^{3}$ Department of Radiodiagnosis, Manipal Academy of Higher Education, Kasturba Medical College, Manipal, Karnataka, India
\end{abstract}

\section{Correspondence to Dr Lakshmikanth Halegubbi Karegowda, hkkanha@gmail.com}

Accepted 23 May 2018

Check for updates

To cite: Kyalakond K, Saini S, Rajagopal K, et al. BMJ Case Rep Published Online First: [please include Day Month Year]. doi:10.1136/bcr-2018225177

\section{DESCRIPTION}

A 47-year-old woman came with the complaints of on-and-off constipation for 6 months with the inability to pass stool for 2 days. She also complained of poor urinary stream and increased urine frequency for 1 year and had a history of hysterectomy with bilateral salpingo-oophorectomy. Her general and systemic examinations were unremarkable. Abdominal radiograph revealed diffuse opacification of the pelvis with left lateral displacement and compression of the rectal shadow (figure 1A). CT of abdomen and pelvis (figure $1 \mathrm{~B}-\mathrm{F}$ ) revealed a large, well-defined heterogeneously enhancing lobulated lesion in the presacral region and central pelvis showing multiple coarse calcifications within. The lesion was abutting the distal sigmoid colon and rectum causing their left lateral displacement with luminal compression and loss of intervening fat plane. There was resultant dilatation of the large and distal small bowel loops suggestive of intestinal obstruction. The fat plane between the lesion and the urinary bladder was also lost suggestive of adherence or infiltration. No direct endoluminal invasion into the bowel or bladder was seen. The patient further underwent MRI of the lumbosacral spine to rule out neurogenic cause for her symptoms. On MRI (figure 1G-I), the visualised portion of the pelvic lesion was heterogeneous with peripheral enhancing solid areas and central large non-enhancing necrotic area. The solid areas were isointense on T1 sequence and hyperintense on the T2 sequence. No abnormality of the conus medullaris or nerve root compression was detected. The imaging differentials that we considered were neurogenic tumour, gastrointestinal stromal tumour (GIST) and soft-tissue sarcoma. A neurogenic tumour could explain all the imaging features. GIST and sarcomatous lesion also would have most of these imaging features except for the presence of multiple calcifications, which is a relatively uncommon feature in them.

The patient was taken up for laparotomy and tumour excision under spinal anaesthesia. However, due to adhesion of the lesion to colon and the bladder, only debulking of the lesion was performed. Histopathological examination (figure 2) revealed typical whorls of meningothelial epithelioid cells, which were reactive to epithelial membranous antigen on immunohistochemistry suggestive of meningothelial meningioma (WHO grade I).

The extracranial meningiomas are rare tumours most commonly occurring in the head and neck region ( $0.9 \%$ to $2 \%$ incidence) with their occurrence in pelvis being even more rarer. The prefix 'primary' indicates that the lesion has no connection to the central nervous system and the theories to explain their origin include misplaced extradural arachnoid cell during embryogenesis, ectopic embryonic arachnoid cells rest growth, arachnoid cells rest migration along the nerve sheaths of cranial nerve or differentiation from perineural cells. ${ }^{1}$

Few articles studying the pathological appearance of these lesions within the pelvis are described. ${ }^{12}$ However, there is no published literature describing their radiological appearance at this location. Morphologically, our lesion demonstrated lobulated outline, typical multiple internal calcifications and good postcontrast enhancement as seen with intracranial meningiomas. Additionally, the lesion

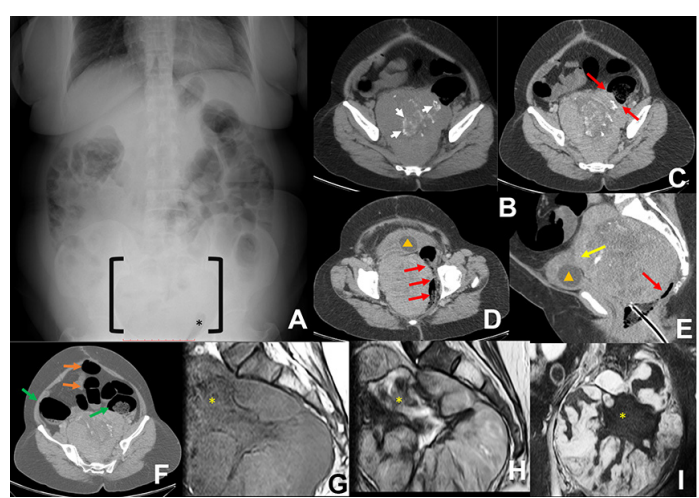

Figure 1 (A) Abdominal radiograph showing diffuse opacification of the pelvis (area between the black brackets) with displacement and compression of the rectal shadow (black asterisk). (B) Plain CT section of the pelvis showing large well-defined lobulated lesion in the presacral region and central pelvis with multiple coarse calcifications (white short arrows). (C-F) Postcontrast axial $(C, D, F)$ and sagittal (E) CT images of pelvis showing enhancement of the lesion, which is causing left lateral displacement and compression of the adjacent distal sigmoid colon and the rectum with loss of intervening fat plane (red arrows). The lesion is also abutting the urinary bladder wall with loss of intervening fat plane (yellow arrow). Resultant dilatation of the large bowel (green arrows) and distal small bowel loops (orange arrows) is seen in image (F). The Foley bulb within the urinary bladder is marked in orange arrowhead in images (D) and (E). On sagittal T1-weighted (G), sagittal T2-weighted $\mathrm{H}$ ) and coronal postcontrast T1-weighted (I) MR images, the lesion shows enhancing solid peripheral areas that are isointense on T1-weighted and hyperintense on T2weighted images with a large central non-enhancing necrotic area (yellow asterisk). 


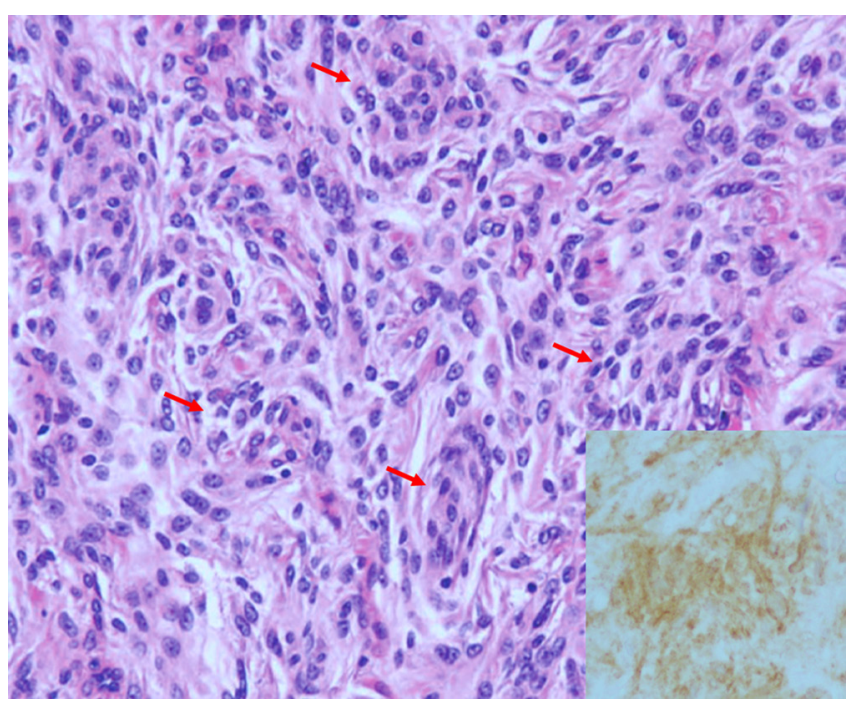

Figure 2 Histopathological examination image shows typical whorls of meningothelial epithelioid cells (red arrows) with tumour cells reactive to epithelial membranous antigen on immunohistochemistry (inset in lower right corner) suggestive of meningothelial meningioma (WHO grade I).

attaining a large size with large central areas of necrosis, its adherence to the pelvic viscera and exertion of mass effect on bowel and bladder leading to intestinal obstruction and increased urinary frequency are few interesting features to note. Among these features, the adherence to adjacent viscera appears to be a characteristic feature as it was also observed in the case study by Nur et al. ${ }^{1}$ The presence of large central necrosis in this benign type of meningioma (WHO grade I) can be secondary to central infarction that occurs within the large lesion as it outgrows the vascular supply (ischaemic necrosis). ${ }^{3}$ Also, the vascularity in the pelvis is much lesser than the vascularity of brain where these tumours are well perfused and less necrotic.

\section{Learning points}

- Primary extracranial meningiomas are rare tumours most commonly occurring in the head and neck region (incidence of $0.9 \%$ to $2 \%$ ) with their occurrence in pelvis being even more rarer.

- Morphological features of the lesion resemble their intracranial counterparts.

- Within the pelvis, they can adhere to the bowel loops causing their compression and intestinal obstruction.

Contributors KK was involved in designing, drafting the work and final approval of the version to be published. SS was involved in conception, drafting the work and final approval of the version to be published. KR was involved in the acquisition, revising the work critically for important intellectual content and final approval of the version to be published. LHK was involved in the analysis of data, drafting the work and final approval of the version to be published. All the authors agree to be accountable for all aspects of the work in ensuring that questions related to the accuracy or integrity of any part of the work are appropriately investigated and resolved.

Funding The authors have not declared a specific grant for this research from any funding agency in the public, commercial or not-for-profit sectors.

Competing interests None declared.

Patient consent Obtained.

Provenance and peer review Not commissioned; externally peer reviewed.

(C) BMJ Publishing Group Ltd (unless otherwise stated in the text of the article) 2018. All rights reserved. No commercial use is permitted unless otherwise expressly granted.

\section{REFERENCES}

1 Nur S, Chuang L, Ramaswamy G. Primary extracranial meningioma of the pelvis: a light microscopic, immunohistochemical, and ultrastructural study. Gynecol Oncol 2006;103:745-8.

2 Lee SY, Kim JH, Kim MJ, et al. Primary retroperitoneal meningioma: a case report. Basic Appl Pathol 2010;3:63-6

3 McDowell D, Harper CG. Central tumour necrosis: a cause for the acute presentation of benign meningiomas. Aust N Z J Surg 1991;61:553-6.

Copyright 2018 BMJ Publishing Group. All rights reserved. For permission to reuse any of this content visit http://group.bmj.com/group/rights-licensing/permissions.

BMJ Case Report Fellows may re-use this article for personal use and teaching without any further permission.

Become a Fellow of BMJ Case Reports today and you can:

- Submit as many cases as you like

- Enjoy fast sympathetic peer review and rapid publication of accepted articles

- Access all the published articles

- Re-use any of the published material for personal use and teaching without further permission

For information on Institutional Fellowships contact consortiasales@bmjgroup.com

Visit casereports.bmj.com for more articles like this and to become a Fellow 